\title{
PERBANDINGAN MODEL PEMBELAJARAN DISCOVERY LEARNING DAN PROBLEM BASED LEARNING TERHADAP HASIL BELAJAR BIOLOGI SISWA KELAS X SMA NEGERI 14 BULUKUMBA TAHUN 2019
}

\author{
Satriani \\ Program Study Pendidikan Biologi STKIP Yapti Jeneponto \\ satrianitanti@gmail.com
}

\begin{abstract}
ABSTRAK
Penelitian ini membahas mengenai perbandingan model pembelajaran Discovery Learning dan Problem Based Learning terhadap hasil belajar biologi siswa kelas X SMA Negeri 14 Bulukumba. Jenis penelitian yang digunakan adalah eksperimen semu (quasy-eksperimen). Populasi penelitian ini adalah seluruh siswa kelas X SMA Negeri 14 Bulukumba dengan jumlah 59 siswa. Teknik pengambilan sampel yang digunakan dalam penelitian ini adalah teknik Random Sampling. Teknik pengumpulan data yang digunakan adalah instrumen tes berbentuk pilihan ganda sejumlah 25 nomor. Teknik analisis data dilakukan dengan menggunakanan analisis statistik deskriptif dan analisis statistik inferensial. Hasil penelitian yang diperoleh adalah hasil belajar siswa yang belajar dengan menggunakan model pembelajaran Discovery Learning dalam kategori tinggi dengan skor rata-rata 84,5 dan hasil belajar siswa yang belajar dengan menggunakan model pembelajaran Problem Based Learning dalam kategori sedang dengan skor rata-rata 80,0 . Hasil perhitungan uji $\mathrm{t}$ diperoleh nilai $\mathrm{t}_{\text {hitung }}$ yaitu $\mathrm{t}_{\text {hitung }} 2,77>\mathrm{t}_{\text {tabel }} 2,024$, sehingga dapat disimpulkan bahwa terdapat perbedaan yang signifikan dari penggunaan model pembelajaran Discovery Learning dan Problem Based Learning terhadap hasil belajar biologi siswa kelas X SMA Negeri 14 Bulukumba, sehingga $\mathrm{H}_{0}$ ditolak dan $\mathrm{H}_{1}$ diterima.

Kata Kunci: Model Pembelajaran Discovery Learning; Model Pembelajaran Problem Based Learning; Hasil Belajar.
\end{abstract}

\begin{abstract}
.
This study discusses the comparison of the Discovery Learning model and Problem Based Learning to the biology learning outcomes of Grade X students of SMA Negeri 14 Bulukumba. This type of research is quasiexperimental research. The population of this study was all students of class X SMA Negeri 14 Bulukumba with a total of 59 students. The sampling technique used in this study is the Random Sampling technique. Data collection techniques used were multiple choice test instruments with 25 numbers. Data analysis techniques were performed using descriptive statistical analysis and inferential statistical analysis. The results obtained are the learning outcomes of students who learn by using the Discovery Learning learning model in the high category with an average score of 84.5 and the learning outcomes of students who learn by using the Problem Based Learning learning model in the medium category with an average score of 80,0. The results of the t test calculations obtained the value of tcount is 2.77> ttable 2.024, so it can be concluded that there are significant differences from the use of the Discovery Learning and Problem Based Learning models towards the biology learning outcomes of class X students of SMAN 14 Bulukumba, so HO is rejected and H1 received.

Keywords: Discovery Learning, Problem Based Learning, Learning outcomes.
\end{abstract}

\section{Pendahuluan}

Pendidikan sangat penting dalam menciptakan generasi penerus bangsa yang berkualitas dan memiliki keterampilan. Dewasa ini bangsa indonesia dituntut bersaing disegala bidang. Hal ini harus diiringi dengan kesiapan generasi penerus bangsa baik mental, spiritual, keterampilan dan wawasan yang dapat menunjang kondisi tersebut. Semua itu dapat terlaksana dengan baik apabila dibidang pendidikan terus diperhatikan sehingga mutu pendidikan dapat terus ditingkatkan.

Pendidikan merupakan salah satu kunci keberhasilan dalam pembangunan nasional di Indonesia. Undang-undang Sistem Pendidikan Nasional No. 20 Tahun 2003 Bab 1 Pasal 1 Ayat 1 menjelaskan bahwa:

"Pendidikan adalah usaha sadar dan terencana untuk mewujudkan suasana belajar dan proses pembelajaran agar peserta didik secara aktif mengembangkan potensi dirinya untuk memiliki kekuatan spiritual keagamaan, pengendalian diri, kepribadian, kecerdasan, akhlak mulia, serta keterampilan yang diperlukan dirinya, masyarakat, bangsa, dan Negara. Untuk mencapai tujuan pendidikan nasional pemerintah telah menyelenggarakan perbaikanperbaikan peningkatan mutu pendidikan pada bebagai jenis dan jenjang." (Mulyasa, 2013).

Salah satu masalah pokok dalam pembelajaran pada pendidikan formal (sekolah) dewasa ini adalah masih rendahnya daya serap peserta didik. Hal ini nampak rerata hasil belajar peserta didik yang senantiasa masih sangat memprihatinkan. Keadaan tersebut tentunya merupakan hasil kondisi pembelajaran yang masih bersifat konvensional dan tidak menyentuh ranah dimensi peserta didik itu sendiri, yaitu bagaimana sebenarnya belajar itu (belajar untuk belajar). Dalam arti yang lebih substansial, bahwa proses pembelajaran hingga 
dewasa ini masih memberikan akses bagi anak didik untuk berkembang secara mandiri melalui penemuan dan proses berfikirnya (Trianto, 2008). Untuk itu diperlukan model pembelajaran yang membuat siswa mendapatkan peluang dalam mengembangkan potensi yang dimiliki selama proses pembelajaran.

Sejauh ini, pembelajaran masih didominasi oleh pandangan bahwa pengetahuan sebagai fakta untuk dihapal. Pembelajaran tidak hanya difokuskan pada pemberian pembekalan kemampuan pengetahuan yang bersifat teoritis saja, akan tetapi bagaimana agar pengalaman belajar yang dimiliki siswa itu senantiasa terkait dengan permasalahan-permasalahan aktual yang terjadi di lingkungan. Dengan demikian, diperlukan adanya model pembelajaran yang mampu mengaitkan pengalaman belajar siswa dengan permasalahan yang terjadi di lingkungan. Model pembelajaran yang menekankan pada kegiatan siswa untuk menemukan dan mengkonstruksikan pengetahuannya sendiri. Melalui proses asimilasi dan akomodasi ini diharapkan dapat memacu meningkatkan kualitas pembelajaran di sekolah, sehingga sekaligus dapat meningkatkan hasil belajar siswa (Rusman, 2013). Melihat permasalahan tersebut diharapkan cocok untuk menerapkan dua model pembelajaran yaitu model pembelajaran Discovery Learning dan model pembelajaran Problem Based Learning.

Pembelajaran biologi pada materi komponen ekosistem memiliki konsep yang sangat berkaitan erat dengan kehidupan sehari-hari dan pengalaman yang sering dialami oleh peserta didik. Pendidikan Biologi diharapkan dapat menjadi wahana bagi siswa untuk mempelajari diri sendiri dan alam sekitarnya, serta prospek pemahaman lebih lanjut dalam menerapkan di dalam kehidupan sehari-hari khususnya pada materi komponen ekosistem. Ekosistem merupakan ilmu yang mengkaji tentang hubungan timbal balik antara individu dan lingkungannya, baik dari segi biotik maupun abiotik (Sukarsono, 2009). Oleh karena itu, dalam proses pembelajaran dengan menggunakan model Discovery Learning dan Problem Based Learning (PBL) peserta didik akan lebih aktif dalam mencari, mengolah dan memahami konsep dan hubungan dalam proses intuitif untuk menyelesaikan masalah mengenai konsep materi komponen ekosistem yang dikaitkan dengan masalah nyata yang sering dialami.

Berdasarkan uraian di atas maka peneliti tertarik untuk melakukan penelitian yang berjudul "Perbandingan Model Discovery Learning Dan Problem Based Learning terhadap Hasil Belajar Biologi Siswa Kelas X SMA Negeri 14 Bulukumba" untuk mengetahui ada tidaknya perbedaan hasil belajar siswa kelas X SMA Negeri 14 Bulukumba yang diajar melalui model pembelajaran Discovery Learning dengan Problem Based Learning

\section{Metode Penelitian}

Pada dasarnya penelitian ini bertujuan untuk menguji ada tidaknya perbedaan hasil belajar siswa kelas X SMA Negeri 14 Bulukumba yang diajar melalui model pembelajaran Discovery Learning dengan Problem Based Learning, dengan memanipulasi variabel bebas model Discovery Learning dengan Problem Based Learning, dan variabel terikat yaitu hasil belajar yang tidak dapat dikontrol secara ketat sehingga jenis penelitian yang digunakan dalam penelitian ini adalah eksperimen semu (quasy eksperiment). Desain eksperimen semu yang digunakan dalam penelitian ini adalah Nonequivalent Control Group Desaign.

Dalam penelitian ini populasi yang digunakan adalah seluruh siswa kelas X SMA Negeri 14 Bulukumba dengan jumlah 59 siswa. Untuk pengambilan sampel menggunakan Random Sampling. Didapatkan kelompok eksperimen ${ }^{1}$ berjumlah 20 orang peserta didik dan kelompok eksperimen ${ }^{2}$ berjumlah 20 orang peserta didik.

Pengumpulan data digunakan instrumen tes dan observasi. Tes yang digunakan untuk menilai hasil belajar peserta didik dan observasi merupakan instrumen pendukung untuk instrumen inti. Data tentang nilai hasil belajar peserta didik pada pokok bahasan komponen ekosistem diambil dari nilai pretest dan postest. Untuk uji prasyarat analisis menggunakan uji normalitas, uji homogenitas varians menggunakan uji F, dan uji hipotesis menggunakan uji t-test Polled Varians dua pihak.

\section{Pembahasan}

Hasil analisis data menunjukkan hasil pretest dan posttest pada kelompok eksperimen 1 (model pembelajaran Discovery Learning) diperoleh nilai ratarata hasil belajar biologi meningkat setelah dilakukan perlakuan, yakni nilai rata-rata pretest adalah 48,9 sedangkan nilai rata-rata posttest adalah 84,5 dengan selisih sebanyak 35,6. Sedangkan hasil analisis data menunjukkan hasil pretest dan posttest pada kelompok eksperimen 2 (model pembelajaran Problem Based Learning) diperoleh nilai rata-rata hasil belajar biologi juga meningkat setelah dilakukan perlakuan, yakni nilai rata-rata pretest adalah 48,87 sedangkan nilai rata-rata posttest adalah 80 dengan selisih sebanyak 31,13 .

Berdasarkan uji hipotesis dengan menggunakan uji t-test Polled Varians dua pihak bertujuan untuk menetapkan ada tidaknya perbedaan yang signifikan antara skor hasil belajar biologi siswa yang dicapai oleh kelas eksperimen $\mathrm{X}_{1}$ (model pembelajaran Discovery Learning) dan kelas eksperimen $\mathrm{X}_{2}$ (model pembelajaran Problem Based Learning), dimana kriteria pengujian hipotesis, "jika $\mathrm{t}_{\text {hitung }}<\mathrm{t}_{\text {tabel }}$, maka $H_{O}$ diterima dan $H_{1}$ ditolak dan jika $\mathrm{t}_{\text {hitung }}>\mathrm{t}_{\text {tabel }}$ maka $H_{o}$ ditolak dan $H_{1}$ diterima. Dari hasil analisis data menunjukkan bahwa $t_{\text {hitung }}=$ $2,77>t_{\text {tabel }}=2,024$ dengan taraf nyata $\alpha=0,05$ dan $\mathrm{dk}=38$.

Dengan demikian dapat disimpulkan bahwa terdapat perbedaan yang signifikan hasil belajar biologi pada siswa kelas X SMA Negeri 14 
Bulukumba dengan penerapan model pembelajaran Discovery Learning dan Problem Based Learning, yang juga dibuktikan dengan data statistik yang menunjukkan nilai rata-rata hasil belajar siswa (posttest) kelas eksperimen 1 adalah 84,5 dan nilai rata-rata hasil belajar siswa (post-test) kelas eksperimen 2 adalah 80,00. Sehingga dapat dikatakan bahwa kelompok eksperimen 1 yang belajar dengan menggunakan model Discovery Learning memiliki rata-rata lebih tinggi.

Berdasarkan hasil penelitian yang telah dilakukan pada kelas $\mathrm{X}_{1}$ SMA Negeri 14 Bulukumba sebagai kelas eksperimen 1 yang belajar dengan menggunakan model pembelajaran Discovery Learning diperoleh data Analisis dari 20 siswa yang dijadikan sebagai sampel penelitian menunjukkan bahwa 14 orang siswa $(70 \%)$ memperoleh skor dengan kategori tinggi, 5 orang siswa $(25 \%)$ memperoleh skor dengan kategori sedang, dan 1 orang siswa (5\%) memperoleh skor dengan kategori rendah.

Berdasarkan data tersebut dapat disimpulkan bahwa hasil belajar siswa yang belajar dengan menggunakan model Discovery Learning termasuk pada kategori tinggi dengan jumlah siswa 14 orang (70\%) dan nilai rata-rata (mean) yang diperoleh yaitu 84,5. Hal ini didukung karena penerapan model Discovery Learning memberi pengalaman baru dalam proses belajar peserta didik. Guru menyajikan permasalahan berupa pertanyaan mengenai materi di dalam LKS (Lembar Kerja Siswa) tentang komponenkomponen ekosistem, dari permasalahan tersebut peserta didik diminta untuk mecari informasi yang sesuai dengan masalah yang disajikan melalui penyelidikan yang dilakukan peserta didik dengan memanfaatkan lingkungan sekitar.

Hasil penelitian yang diperoleh pada penelitian ini sejalan dengan penelitian yang telah dilakukan oleh Aryanti Indah Jaya pada tahun 2010 dengan judul "Perbandingan Penerapan Model Discovery Learning dengan Metode Ceramah Bervariasi terhadap Hasil Belajar Biologi Siswa kelas X SMA Negeri 2 Palopo". Dalam penelitiannya ini didapatkan hasil bahwa dengan model Discovery Learning pada konsep pencemaran lingkungan membuat siswa lebih aktif mencurahkan pemikirannya, siswa dapat belajar mengingat, menerapkan, dan melanjutkan proses pembelajaran secara mandiri sehingga siswa tidak menghapal materi serta memberi kebebasan bagi siswa untuk mengimplementasikan pengetahuan atau pengamalaman yang dimilikinya untuk memecahkan masalah (Jaya, 2010).

Berdasarkan hasil penelitian yang telah dilakukan pada kelas $\mathrm{X}_{2}$ SMA Negeri 14 Bulukumba sebagai kelas eksperimen 2 yang belajar dengan menggunakan model Problem Based Learning diperoleh data analisis dari 20 siswa yang dijadikan sebagai sampel penelitian menunjukkan bahwa 9 orang siswa $(45 \%)$ memperoleh skor dengan kategori tinggi dan 11 orang siswa $(55 \%)$ memperoleh skor dengan kategori sedang. Begitupun jika dilihat dari nilai rata-rata (mean) yang diperoleh yaitu 80,0 maka hasil belajar siswa yang belajar dengan menggunakan model pembelajaran Problem Based Learning dapat dikategorikan berada pada kategori sedang. Hal ini didukung karena model Problem Based Learning peserta didik dihadapkan pada masalah nyata sebagai sarana bagi peserta didik untuk mengembangkan pengetahuan, kemampuan berpikir kritis dan kemampuan pemecahan masalah. Sehingga sebagian besar peserta didik secara aktif dan kritis mengidentifikasi informasi dan strategi yang relevan serta melakukan penyelidikan untuk menyelasaikan masalah yang diberikan oleh guru. Dengan menyelesaikan masalah tersebut melalui proses diskusi, peserta didik memperoleh atau membangun pengetahuan tertentu, memperoleh pengalaman serta meningkatkan pemahaman tentang apa yang dipelajari sehingga peserta didik dapat menerapkannya dalam kondisi nyata pada kehidupan sehari-hari.

Hasil yang diperoleh pada penelitian ini hampir sama dengan penelitian yang telah dilakukan oleh Toha Nasruddin pada tahun 2014 dengan judul "Penerapan Model Problem Based Learning (PBL) sebagai Upaya Peningkatan Partisipasi dan Prestasi Belajar Siswa Kelas $\mathrm{X}_{\mathrm{B}}$ MAN Tempel Yogyakarta pada Pokok Bahasan Keanekaragaman Hayati”. Dalam penelitiannya diperoleh bahwa penerapan model pembelajaran Problem Based Learning (PBL) pokok bahasan keanekaragaman hayati siswa terlihat antusias dan tertarik dalam mengikuti pembelajaran (Nasruddin, 2014).

Berdasarkan uji hipotesis perbedaan antara nilai post-test kelas eksperimen 1 dan eksperimen 2, diperoleh nilai $\mathrm{t}$ hitung sebesar 2,77 pada taraf kesalahan 0,05 (5\%) diperoleh nilai $\mathrm{t}_{\text {tabel }}$ sebesar 2,024 berdasarkan ketentuan kriteria pengujian hipotesis, "jika $t_{\text {hitung }}<\mathrm{t}_{\text {tabel }}$, maka $H_{O}$ diterima dan $H_{1}$ ditolak dan jika $t_{\text {hitung }}>\mathrm{t}_{\text {tabel }}$ maka $H_{o}$ ditolak dan $H_{1}$ diterima. Dari hasil analisis data nilai $t_{\text {hitung }}$ lebih besar dari pada $\mathrm{t}_{\text {tabel }}$ yaitu $(2,77>2,024)$. Dengan demikian $\mathrm{H}_{0}$ ditolak dan $\mathrm{H}_{1}$ diterima, berarti dapat disimpulkan bahwa terdapat perbedaan yang signifikan hasil belajar biologi pada siswa kelas X SMA Negeri 14 Bulukumba dengan penerapan model pembelajaran Discovery Learning dan Problem Based Learning, yang dibuktikan dengan data statistik yang menunjukkan bahwa nilai rata-rata pada kelompok eksperimen 1 yang belajar dengan menggunakan model Discovery Learning berada pada kategori tinggi sedangkan kelompok eksperimen 2 yang belajar dengan menggunakan model Problem Based Learning berada pada kategori sedang.

Menurut Hosnan (2014), dalam teori yang dikemukakan oleh Jerome Bruner bahwa untuk menunjang proses belajar, perlu lingkungan yang memfasilitasi rasa ingin tahu peserta didik pada tahap eksplorasi. Lingkungan ini dinamakan Discovery Learning Environment, yaitu lingkungan di mana peserta didik dapat melakukan eksplorasi, penemuan- 
penemuan baru yang belum dikenal atau pengertian yang mirip dengan yang sudah diketahui.

Penerapan model pembelajarn Problem Based

Learning siswa dihadapkan pada masalah nyata sebagai pemicu bagi proses belajar peserta didik sebelum mereka mengetahui konsep formal. Dengan mengaitkan masalah nyata dan konsep pengetahuan, sebagian besar peserta didik aktif mengidentifikasi informasi yang relevan serta melakukan penyelidikan untuk menyelasaikan masalah yang diberikan oleh guru. Pengalaman siswa yang diperoleh dari masalah nyata yang terjadi di lingkungan sekitar mereka akan menjadikan kepadanya bahan dan materi guna memperoleh pengertian serta bisa dijadikan pedoman dan tujuan belajarnya. Hal ini sesuai dengan teori yang dikemukakan oleh H.S Barrows sebagai pakar Pembelajaran Berbasis Masalah menyatakan bahwa Pembelajaran Berbasis Masalah adalah sebuah metode pembelajaran yang didasarkan pada prinsip bahwa masalah (problem) dapat digunakan sebagai titik awal untuk mendapatkan atau mengintegrasikan ilmu baru (Hamalik, 2009).

\section{Kesimpulan}

Hasil perhitungan uji t-test Polled Varians dua pihak diperoleh nilai $\mathrm{t}_{\text {hitung }}$ yaitu $\mathrm{t}_{\text {hitung }} 2,77>\mathrm{t}_{\text {tabel }} 2,024$, sehingga dapat disimpulkan bahwa terdapat perbedaan yang signifikan dari penggunaan model Discovery Learning dan Problem Based Learning terhadap hasil belajar biologi siswa kelas X SMA Negeri 14 Bulukumba. Pencapaian rata-rata hasil belajar siswa kelompok eksperimen ${ }_{1}\left(\mathrm{X}_{1}\right)$ yang belajar dengan menggunakan model Discovery Learning lebih tinggi dibandingkan dengan kelompok eksperimen ${ }_{2}\left(\mathrm{X}_{2}\right)$ yang belajar dengan menggunakan model Problem Based Learning. Dengan demikian model Discovery Learning lebih efektif digunakan dalam proses pembelajaran biologi khususnya pada pokok bahasan komponen ekosistem.

\section{Daftar Pustaka}

Hamalik, Oemar. Proses Belajar Mengajar. Cet. 10; Jakarta: Bumi Aksara, 2009.

Hosnan. Pendekatan Saintifik dan Kontekstual dalam Pembelajaran Abad 21. Cet I. Bogor: Ghalia Indonesia, 2014.

Jaya, Aryanti Indah. Perbandingan Penerapan Model Discovery Learning dengan Metode Ceramah Bervariasi terhadap hasil belajar Biologi Siswa kelas X SMA Negeri 2 Palopo. Semarang: Fakultas Ilmu Pendidikan UNS, 2010.

Mulyasa. Pengembangan dan Implementasi Kurikulum 2013. Cet III; Bandung: PT Remaja Rosda Karya, 2013.

Nasruddin, Toha. Penerapan Model Pembelajaran Problem Based Learning (PBL) sebagai Upaya Peningkatan Partisipasi dan Prestasi Belajar Siswa Kelas $\mathrm{X}_{\mathrm{B}}$ MAN Tempel Yogyakarta pada Pokok Bahasan Keanekaragaman Hayati. Joernal. Yogyakarta: Universitas Negeri Yogyakarta, 2014.

Putra, Sitiavana Rizema. Desain Belajar Mengajar Kreatif Berbasis Sains. Cet. I; Jogjakarta: DIVA Press, 2013.

Rusman. Model-Model Pembelajaran Mengembangkan Profesionalisme Guru. Edisi 2. Cet VI; Jakarta: PT Raja Grafindo Persada, 2013.

Sukarsono. Ekologi Hewan: Konsep, Perilaku, Psikologi, dan komunitas. Cet. I; Malang: UMM Press, 2009.

Trianto. Mendesain Pembelajaran Kontekstual Teaching And Learning di Kelas. Cet I; Jakarta: Cerdas Pustaka Publisher, 2008. 